\title{
Some Aspects of the Prevention and Treatment of Felon
}

\author{
Shaposhnikov Veniamin Ivanovich* \\ Kuban Medical Institute, Professor of surgical diseases, Russia
}

*Corresponding author: Shaposhnikov Veniamin Ivanovich, Professor of surgical diseases, Noncommercial educational private institution of higher education, Kuban Medical Institute, Vice Rector, Russia

\begin{tabular}{|c|c|}
\hline ARTICLE INFO & ABSTRACT \\
\hline Received: 蔧 April 30, 2019 & In outpatient surgical practice the author proposes for prevention and treatment \\
\hline Published: 幽 May 02, 2019 & of felon use ointments and not coagulable antiseptic substances and persistent wet- \\
\hline $\begin{array}{l}\text { Citation: Shaposhnikov Veniamin Iva- } \\
\text { novich. Some Aspects of the Preven- } \\
\text { tion and Treatment of Felon. Biomed } \\
\text { J Sci \& Tech Res 17(4)-2019. BJSTR. } \\
\text { MS.ID.003042. }\end{array}$ & $\begin{array}{l}\text { without removing it, the patient performs independently (under the supervision of a } \\
\text { physician clinics). The duration of treatment varies from } 2 \text { to } 5 \text { days. Effect of constant } \\
\text { hyperosmolarity bandages, fabric detritus is not accumulated in the cavity wounds and } \\
\text { absorbed in it. When eliminating the threat of a festering wound, or it is cleaned of necrotic } \\
\text { tissues, use or dry aseptic, or ointment (levomekolju) dressing. The method is applied in } \\
\text { more than } 1000 \text { patients and all have received favorable treatment. The author notes not }\end{array}$ \\
\hline $\begin{array}{l}\text { Keywords: Brush; Ran; Whitlow; Band- } \\
\text { age; Constant; Wet-Drying Up }\end{array}$ & $\begin{array}{l}\text { only the effectiveness of this treatment, but its simplicity and cheapness. The purpose of } \\
\text { the study shows the advantage of wet-dry dressings in the prevention and treatment of } \\
\text { felon, over traditional methods of therapy. }\end{array}$ \\
\hline
\end{tabular}

\section{Introduction}

Microtrauma and bacterial contamination of the hands are the main reasons for the development of the felon. In outpatient practice surgeon acute inflammatory processes in the field of fingers hold $64-69 \%$ from the total number of patients presenting at purulent surgical diseases [1-3]. During the year, this disease affects 0.5 $1.0 \%$ of the population of the world's leading economies, with a temporary diminution of them occurs in $8-10 \%$. From $90-95 \%$ of patients ages 18 to 50 years old. Severe forms of felon (tendon, bone, joint, pandaktilit) occur in $25 \%$. Duration of treatment in these patients reaches two months and even more and often ends with amputation phalanx or finger. This is usually the original irrational treatment method of light forms of felon, or ineffective its prevention [1-3]. Typically, patients with severe odds felon, before entering the hospital, during the 9-15 days are observed in clinics and the $75-80 \%$ of initial abscess autopsy brush and $45-55 \%$-and repeated. Apply mid-side cuts on fingers and poluovalnye in the Palm of your hand. In the end phalanx thumb use kljushkovidnyj cut [4-6].

Supportive foci promyvaju antiseptic solution, and then drainages rubber strips, followed on purulent wound impose remedies, or with an aqueous solution of sodium chloride (10\%), or dimexida or chlorhexidine or another antiseptic. When Reoperation usually apply levomekol. After the operation, patients are released back home. On the day they come to the clinic the following day. During this time the bandage dries out and turns into a cake, i.e. no suction function in it anymore. This is reflected on the correction of the inflammatory process in the brush area is growing soft tissue edema $[7,8]$. Use the same physical purification methods of purulent wounds (ultrasound), due to the short duration of exposure procedure does not give the desired effect-microflora quickly recovers. Has not lived up to expectations and antibiotic treatment. 90-93\% of patients have pathogens nagnoenia tissues brushes are staphylococci, which little or insensitive to synthetic penicillin's, cephalosporin's, aminoglycosines, meroneum and other drugs. A situation in which difficult treatment of this widespread disease.

In the prevention of same felon has great value defining the severity of damage to the brush and immune status organism to avoid mistakes in choosing surgical treatment algorithm or a victim. Of great importance in the prevention nagnoenia wounds give her blood purification mechanically, which comes from her depths. It has been established that the dryness of the skin around the wound and her omozolelost, only contribute to the development of the inflammatory process. When processing the edges of wounds 
spirtsoderjasimi liquids, comes chemical burn them. This leads to the zamurovyvaniju microorganisms present in the wound and creates conditions for their reproduction. For this reason, offer to lubricate the skin around the area not microtrauma 5-10\% tincture of iodine, and a mixture of the following composition: Glycerin $900 \mathrm{~g}$ $+100 \mathrm{~g} 2 \%$ tincture of iodine $[1,6]$. These data reflect the economic importance and the relevance of examining issues of prevention and treatment of felon at the present stage of development of the health sector. This allowed us to improve treatment of the pathological process.

\section{Material and Methods}

The study is based on observations on the application of wet-drying turban with a purpose, as a felon, prevention and treatment. Duration of observation varies from 5 to 25 years. They all belonged to the inhabitants of one neighborhood, allowing an objective assessment of the proposed method of prophylaxis and treatment. With the aim of preventing it was applied at 1253 man with skin damage, brush 103 (8.2\%) had extensive injuries, 213 (17\%)-puncture wounds without foreign bodies, 35 (2.8\%)-puncture wounds with foreign bodies, 195 (15.6\%)-sliced, 642 (51.2\%)-fragmentary, 65 (5.2\%)-bite. Patients aged 14 to 50 years of age accounted for $81 \%$ and from 51 to 93 years-19\%. Surgical debridement under anesthesia and wiring according to traditional methods. In the wound left a thick bandage aseptic. She profusely smachivalas $10 \%$ solution of sodium chloride, and the patient released home. As a mandatory element of treatment included an independent permanent 24hour irrigation patient this same bandage sterile solution (without removing it). In 24 hours, the patient spent up to 1 liter of solution. Replacement bandages produced in the clinic once per day. Antibiotics are not prescribed. Duration of use wet-dry dressings was from 4 to 7 days. The procedure stopped after the removal of threats to the development of the felon-no swelling and discharge from the wound. Rehabilitation depended on the nature of the damage. The most prolonged treatment (up to 15 days) was in vast ragged firearm wounds. Wet-drying bandages for the treatment of felon, was applied at 211 patients. They all later sought medical help when after 9-14 days have passed since the microtrauma. Of the 211 patients (53.3\%) and 112 have was subcutaneous form of this disease, 53 (25\%)-osteo-articular, 33 (15.6\%)-suhozhilnaja, 13 (6.1\%)-pandaktilit. Age of patients was from 19 to 75 years.
Opening and draining of purulent foci produced in the normal way and immediately began to apply wet-dryings out bandages on the methodology described above. And depending on the odds of felon this lasted from 7 to 12 days.

\section{Results}

When applying wet-dry dressings to prevent felon, all patients received a favorable result, i.e. none of them had developed the disease. Treatment of all patients with felon without jekzartikuljacii amputation and finger. In patients with percutaneous panariciem managed to keep finger function in full. When other forms of felon treatment continued until months or even more, and 7\% from pandaktilitom come diminution.

\section{Discussion}

The positive effect of wet-dry dressings can be attributed to its constant giperosmoljarnostju-within a few days. This is accompanied by constant circulation of lymph from the depth of the wound, resulting in leaching of microbes from the deep divisions of the wound.

\section{Conclusion}

Thus, the use of wet-drying bandages for prevention and treatment of felon brings not only some clinical, but also the economic impact and for this reason it can be recommended for use in all clinics and hospitals.

\section{References}

1. Kosachov ID (1989) Treatment pandaktilita/Bulletin of surgery pp. $120-112$

2. Meleshevich AV, Felon (2002) Phlegmon of the brush 245s.

3. Usolceva EV, Mashkara KI (1986) Surgery diseases and damage the brush $/ \mathrm{m} 320.6$

4. Gostishev VK (2016) Clinical operational purulent surgery. M.GEOTARMedia pp. 448.

5. Petrov SV (2010) General Surgery,M GEOTAR-MEDIA, 3-ed. 336. and extras pp. 508.

6. Townsend CM, Evers BM (2010) Atlas of General Surgical Techniques pp. 420.

7. Lipatov KV, Sopromadze MA, Emelyanov AYu, Kanorskij ID (2001) Use physical methods in treatment of purulent wounds. Surgery 10: 56-61.

8. Shaposhnikov VI (2003) Use wet-drying casts in the prevention and treatment of felon. Kuban scientific medical bulletin No 1-2-164-166.

\section{ISSN: 2574-1241}

\section{DOI: 10.26717/BJSTR.2019.17.003042}

Shaposhnikov Veniamin Ivanovich. Biomed J Sci \& Tech Res

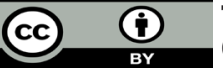

This work is licensed under Creative Commons Attribution 4.0 License

Submission Link: https://biomedres.us/submit-manuscript.php

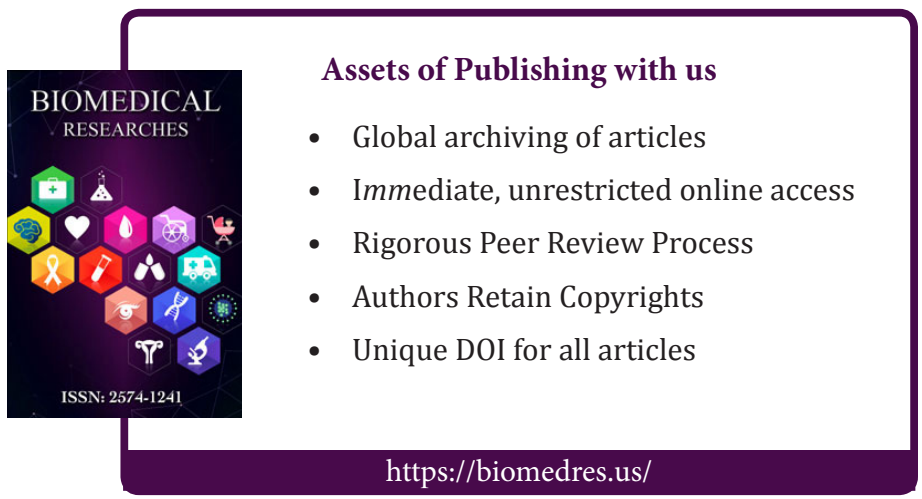

